\title{
Investigation of Cervical Cancer Screening Outcomes
}

\author{
Sibel Simsek ${ }^{1}$ and Aynur Kızılırmak ${ }^{2 *}$ \\ ${ }^{1}$ Nevsehir State Hospital, The Diagnosis Related Group (DRG) Unit, Turkey \\ ${ }^{2}$ Department of Nursing, Nevsehir Haci Bektas Veli University, Nevsehir-Turkey
}

Received: February 25, 2016; Accepted: April 28, 2016; Published: MAy 04, 2016

*Corresponding author: Aynur Kizllırmak, Department of Nursing, Nevsehir Haci Bektas Veli University, Nevsehir-, Semra and Vefa Kucuk Health College, 2000 Evler District, Zubeyde Hanım Street 50300 Nevsehir-Turkey, Tel: +90 38421523 80; Fax: +90 38421523 00; E-mail: aynur268@gmail.com

\begin{abstract}
Objectives: Cervical cancer is the most common cancer among women after breast, and colorectal cancers in the world and an important health problem. This study is a cross sectional retrospective study that was conducted to investigate cervical cancer screening outcomes of women in the middle of Turkey.

Methods: The women who applied between 1 January to 31 December 2013 constituted the universe of the study and also, 1087 women who applied between 1 October to 31 December 2013 and was taken Pap smear constituted the sample of this study. Data was collected by investigating CEDSEC polyclinic documents and cervical cancer Screening and Consent Forms records. Data was evaluated at computer by using SSPS 15.0 (Statistical Program for Social Sciences) package program for analysis, percentage, mean, chi-square and standard deviation. In every stage of the study it is taken care to follow ethical principles. Ethical Council Consent from Nevsehir Haci Bektas Veli University and written consent from Nevsehir City Public Health Directorate.
\end{abstract}

Results: It is determined that $39.1 \%$ of the women were between 40-49 years old and older than 40 years got pap smear tests. When their pap smear outcomes were investigated, it is found that $0.3 \%$ of them got ASCUS, $0.3 \%$ of them got HGSIL. While women aged over 60 who HSIL result of the study we see that before the age of 60 women with ASCUS.

Conclusion: In our study, the woman with HGSIL was older than the others who had ASCUS. This result shows the importance of early diagnosis and screening. For being protected from cervical cancer, to know the factors that could be causes for this disease and importance of early diagnosis are important in terms of taking required measures. Giving educations about this subject to society, especially, groups that under risk, composing awareness related to increase to participation to the screening programs are important roles of nurses.

Keywords: Woman health; Cervical cancer; Screening; Pap smear tes

\section{Introduction}

Cervical cancer is the most common cancer among women after breast, and colorectal cancers in the world and an important health problem. In 2012, it is determined that 528.000 new cases had diagnosis, 266.000 patient dead and this death rate was 7.5 in one hundred thousand related to deaths in women cancers.
Almost $87 \%$ of these deaths are seen the less developed countries which have got 15.7 in one hundred thousand incidence rates. These countries are East Africa with 42.7 peer one hundred thousand people, Melanezya (33.3), South (31.5) and Middle Africa (30.6). While cervical cancer is the most common fourth cancer in the world, in our country its incidence for age is 4.3 in one hundred thousand and 1.7 mortality rate in 100.000 , so it is in twelveth line [1,2]. According to the results of brief report of cancer screening of Turkey public health institute in 2014, in Turkey there are 1500 women with cervical cancer [3].

World Health Organization (WHO) is suggested to be cooperated with themselves for improving programs that increasing quality of life of patients and their families and decreasing cancer mortalities in countries especially with low/ middle income, in 2005 at 58 World Health Council. WHO advise to countries to integrate their cancer control program in health system and improve the programs that evidence based in cancer diagnosis and treatment and sources could be used more efficient in [4]. In Turkey, cervical cancer screening program is done by Turkey Public Health Institute Family Health Centers and Cancer Early Diagnosis, Screening and Education Centers (CEDSEC) in Public Health Centers. There are 126 CEDSEC and 7 of them are mobile. Total numbers of CEDSEC are aimed to be 280 in the late of 2018. At CEDSEC the pap smear screening tests of 30- 65 aged women, outcomes are followed up, and they who are determined as pathologic are directed to women diseases doctors. Screening continues in every 5 years when the outcomes are good [3]. In a lot of studies, it is determined that with Pap smear test preinvasive numbers was more than invasive one [5-10]. These results show a real that early treatment could decrease cervical cancer incidence.

Cervical cancer is at the beginning of the cancers that could be prevented with early diagnosis at women. Until pap smear test is used for early diagnosis and especially in the last 40 years, screening programs are improved in a lot of countries and so, an important decrease has been recorded at invasive cervical cancer incidence. Cervical cancer screening with Pap smear test increased invasive disease diagnosis with cervical intraepithelial neoplasia and decreased cervical cancer incidence and mortality. In any place of the World, incidence and mortality of cervical 
cancer could not be decreased without an active screening program [11,12].

Surgical, radiotherapy and chemotherapy are used in cervical cancer treatment. The most important factor that could determine its prognosis is early diagnosis and when the examination is done as advised it is impossible to determine the cases more than $90 \%$ of them [13]. Cervical cancer screening programs are important in our country, too. To know outcomes of screening tests is important in terms of show the way to recognize the importance of screening tests with further plans and scientific studies. So, this study is aimed to investigate cervical cancer screening outcomes.

\section{Methods}

\section{Study type}

This study is a cross sectional retrospective study that was conducted to investigate cervical cancer screening outcomes in the middle of Turkey.

\section{Study setting and participants}

Totally 5706 women applied to CEDSEC between 1 January 31 December 2013 and pap smear was practiced to 3098 of them. At the first 6 months of 20131170 women applied and at the last 6 months 3936 women applied, at the last 3 months this number was 2239 (Nevsehir city center CEDSEC documents, 2013). The women who applied between January $1^{\text {st }}$-December $31^{\text {st }} 2013$ constituted the universe of the study and also, 1087 women who applied between $1^{\text {st }}$ October-31 ${ }^{\text {st }}$ December 2013 and was taken pap smear constituted the sample of this study.

\section{Inclusion criteria}

The women who pap-smear tests were done.

\section{Exclusion criteria}

The women who applied to CEDSEC but pap-smear tests were not done.

\section{Data collection}

Data was collected by investigating CEDSEC polyclinic documents and cervical cancer screening and consent Forms records.

In CEDSEC polyclinic documents there are some information's as follows; protocol number, name-surname of the women, date of applying, age, region that come from, wanted tests and outcomes of tests (pap-smear).

Cervical cancer screening and consent forms were constituted of 26 questions included in socio demographic, obstetric and gynecological characteristics of the women.

\section{Statistical data analysis}

Data was evaluated at computer by using SSPS 15.0 (Statistical Program for Social Sciences) package program for analysis, percentage, mean, chi-square and standard deviation.

\section{Ethical issues}

In every stage of the study it is taken care to follow ethical principles. Ethical Council Consent from Nevsehir Haci Bektas Veli University (84902927) and written consent from Nevsehir City Public Health Directorate (Tarih: 04.03.2014, no: 47230148/548-1414) were taken.

\section{Results}

In this record screening study, results are limited to data at documents. It is determined that $39.1 \%$ of the women were between $40-49$ years old and older than 40 years got pap smear tests (Table 1).

Mean ages for menarche of them was $13.60 \pm 1.40$. The first

Table 1: Distribution of the women's sociodemographic characteristics

\begin{tabular}{|c|c|c|}
\hline Characteristics & n & $\%$ \\
\hline \multicolumn{3}{|l|}{ Age ( $n$ :1087) } \\
\hline 30-39 years & 69 & 6.3 \\
\hline 40-49 years & 425 & 39.1 \\
\hline 50-59 years & 428 & 39.4 \\
\hline 60 years and over & 165 & 15.2 \\
\hline \multicolumn{3}{|c|}{ Lived region ( $n: 1087)$} \\
\hline City & 101 & 9.3 \\
\hline Town & 276 & 25.4 \\
\hline Village & 710 & 65.3 \\
\hline \multicolumn{3}{|c|}{ Social guarantee $(\mathrm{n}: 830)^{*}$} \\
\hline Yes & 707 & 85.2 \\
\hline No & 123 & 14.8 \\
\hline \multicolumn{3}{|c|}{ Marriage status ( $n: 707)^{*}$} \\
\hline Married & 674 & 91.5 \\
\hline Divorced & 63 & 8.5 \\
\hline \multicolumn{3}{|c|}{ Education status $(n: 683)^{*}$} \\
\hline Illiterate & 107 & 15.7 \\
\hline Primary school & 523 & 76.6 \\
\hline Secondary school & 21 & 3.1 \\
\hline High school & 24 & 3.5 \\
\hline University and up & 8 & 1.2 \\
\hline \multicolumn{3}{|l|}{ Occupation ( $\mathrm{n}: 622)^{*}$} \\
\hline House worker & 608 & 97.7 \\
\hline Officer & 14 & 2.3 \\
\hline \multicolumn{3}{|l|}{ Smoking ( $\mathrm{n}: 860)^{*}$} \\
\hline Smoke & 44 & 5.1 \\
\hline Not smoke & 816 & 94.9 \\
\hline \multicolumn{3}{|c|}{ Drinking alcohol $(\mathbf{n}: 772)^{*}$} \\
\hline Not to drink & 772 & 100 \\
\hline \multicolumn{3}{|c|}{ First marriage age $(\mathrm{n}: 863)^{*}$} \\
\hline 13-19 years & 662 & 76.5 \\
\hline 20-26 years & 184 & 21.3 \\
\hline 27 years old and over & 17 & 2.0 \\
\hline \multicolumn{3}{|c|}{ Number of marriage $(n: 862)^{*}$} \\
\hline 1 & 835 & 96.9 \\
\hline 2 and more & 27 & 3.1 \\
\hline
\end{tabular}


pregnancy age and the first delivery age of the women were between $13-19$ years (61.8\% 55.3\%), the last pregnancy age for $59.4 \%$ of them was $27-36$ years, pregnancy number of them was 4-6 and 1-3 (49.7\%, 59.1\%). Also, $60.8 \%$ of the women didn't use family planning method and duration of using intrauterine device for $90.7 \%$ of them was more than 1 year (Table 2).

It is determined that of the women; $91.5 \%$ didn't take hormone therapy, $62.7 \%$ didn't use any continuous medicine, $61.6 \%$ didn't have got a chronic disease, 93.2\% wasn't patients as gynecological, $8 \%$ had breast cancer in her family, $3.9 \%$ had gynecological cancer in her family (Table 3 ) .

When their pap smear outcomes were investigated, it is found that $0.3 \%$ of them got ASCUS, $0.3 \%$ of them got HGSIL (Table 4 ). The 3 women with HGSIL were 60-64 aged and they were living in the village. There weren't any records related with other information's. Again, for the 3 women with ASCUS socioeconomic characteristics were as follows; one lived in city center, one lived in town a done lived in village. Also, two of them haven't got any social guarantee, all three of them didn't use cigarette or alcohol, married and this was their single marriage, first marriage ages of them was 13-19 years. Of these 3 women with ASCUS; menarche ages were 13, 14, 16 respectively, first pregnancy age range was 13-19. Again, 2 of them had got 4 and more pregnancy, they used intrauterine device, one of them had got chronic disease and used medicine continuously and one of them had got breast cancer in her family. However, in these comparing that above, any meaningful difference only between having social guarantee and number of birth was found as statistically $(p<0.05)$.

\section{Discussion}

In Turkey, cervical cancer screening program is done by CEDSEC in Turkey Public Health Institute Family Health Centers and Public Health Centers. The women 30-65 aged get pap-smear screening and their outcomes are followed. After, they who were determined with pathology are directed to women diseases doctors in other centers. When outcomes are negative, screening is continued in every 5 years [3].

Cervical cancer is a preventable cancer among gynecological cancers because of its long preinvasion stage. Also, effective screening programs could supply early diagnosis for this disease [14]. In developed countries invasive cervical cancer rates decreased with using pap smear screening test at last 30 years [15-17]. So that, in order to decrease cervical cancer frequency, by an effective screening program, supplying the lesions that show invasive cancer is important. Whereby cervical cancer screening program in Taiwan, invasive cancer incidence decreased as $47.8 \%$ rate between 1995-2006 [18]. In our study, ages of 3 women with ASCUS were 37, 53 and 59. The other 3 women with HGSIL were 60-64 aged. When we noticed their age, it is seen that the women with HGSIL were older than the women with ASCUS and this result shows that with early diagnosis and treatment invasive cancer incidence could decrease. T.R. Health Ministry Cancer Department stated that in cervical cancer more than $95 \%$ of the cancer cases could be determined at an early stage (Stage 0,1,2) [19].
Table 2: Obstetric characteristics of the women.

\begin{tabular}{|c|c|c|}
\hline Characteristics & $\mathbf{n}$ & $\%$ \\
\hline Menarche age $(X \pm s d)$ & \multicolumn{2}{|c|}{$13.60 \pm 1.40$} \\
\hline \multicolumn{3}{|c|}{ First pregnancy age $(\mathrm{n}: 855)^{*}$} \\
\hline $13-19$ years & 528 & 61.8 \\
\hline 20-26 years & 298 & 34.8 \\
\hline 27 years old and over & 29 & 3.4 \\
\hline \multicolumn{3}{|c|}{ Fisrt delivery age ( $n: 738)^{*}$} \\
\hline $13-19$ years & 408 & 55.3 \\
\hline 20-26 years & 304 & 41.2 \\
\hline 27 years old and over & 26 & 3.5 \\
\hline \multicolumn{3}{|c|}{ Last pregnancy age $(n: 347)^{*}$} \\
\hline 17-26 years & 92 & 26.5 \\
\hline 27-36 years & 206 & 59.4 \\
\hline 37 years and over & 49 & 14.1 \\
\hline \multicolumn{3}{|c|}{$\begin{array}{l}\text { Number of pregnancy ( } \mathrm{n} \text { : } \\
865)^{*}\end{array}$} \\
\hline $1-3$ & 281 & 32.5 \\
\hline $4-6$ & 430 & 49.7 \\
\hline $7-9$ & 119 & 13.8 \\
\hline 10 and more & 35 & 4.0 \\
\hline \multicolumn{3}{|c|}{ Number of delivery $(\mathrm{n}: 860)^{*}$} \\
\hline 1-3 deliveries & 508 & 59.1 \\
\hline 4-6 deliveries & 319 & 37.1 \\
\hline 7 and over deliveries & 33 & 3.8 \\
\hline \multicolumn{3}{|c|}{ Number of miscarriage $(n: 485)^{*}$} \\
\hline 1 & 224 & 46.2 \\
\hline 2 & 146 & 30.1 \\
\hline 3 & 68 & 14.0 \\
\hline 4 and over & 47 & 9.7 \\
\hline \multicolumn{3}{|c|}{ Family planning method $(\mathrm{n}: \mathrm{852})^{*}$} \\
\hline Not use & 518 & 60.8 \\
\hline IUD & 201 & 23.6 \\
\hline Medicine & 30 & 3.5 \\
\hline Other & 103 & 12.1 \\
\hline \multicolumn{3}{|c|}{ Duration of using IUD $(n: 54)^{*}$} \\
\hline 1 year $\leq$ & 5 & 9.3 \\
\hline 1 year > & 49 & 90.7 \\
\hline
\end{tabular}

In a study of Turkish Cervical Cancer and Cervical Cytology Research Group that was conducted with 33 centers, pap smear outcomes as follows; $1.07 \%$ ASCUS, $0.07 \%$ ASC-H, 0.3\% LSIL, $0.17 \%$ HGSIL [5]. In another study, it is determined that of the cases; $0.83 \%$ were ASCUS, $0.15 \%$ were ASC-H, $0.15 \%$ were LGSIL, $0.05 \%$ were HGSIL and also one patient had carcinoma with squamous cell [6]. In our study, of the women; $0.3 \%$ were ASCUS and $0.3 \%$ were HGSIL. In a study of Nokiani, et al. in Iran, 148.472 smears were evaluated and cytological abnormality was determined in only $0.3 \%$ of them [20]. Our study is almost similar these studies. Again, similar results with other studies in our country are seen [7-10]. 
Table 3: Gynecological characteristics of the women.

\begin{tabular}{|c|c|c|}
\hline Characteristics & n & $\%$ \\
\hline \multicolumn{3}{|c|}{ Hormone therapy $(\mathbf{n}: \mathbf{8 5 0})^{*}$} \\
\hline Take & 72 & 8.5 \\
\hline Not take & 778 & 91.5 \\
\hline \multicolumn{3}{|c|}{ Medicine used cntinuously ( $n: 818)^{*}$} \\
\hline Use & 305 & 37.3 \\
\hline Not use & 513 & 62.7 \\
\hline \multicolumn{3}{|c|}{ Chronic Disease ( $n: 823)^{*}$} \\
\hline Yes & 316 & 38.4 \\
\hline No & 507 & 61.6 \\
\hline \multicolumn{3}{|c|}{ 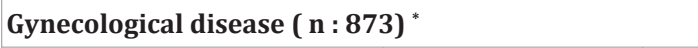 } \\
\hline Yes & 59 & 6.8 \\
\hline No & 814 & 93.2 \\
\hline \multicolumn{3}{|c|}{ Breast cancer in family $(n: 775)^{*}$} \\
\hline Yes & 62 & 8.0 \\
\hline No & 713 & 92.0 \\
\hline \multicolumn{3}{|c|}{ Gynecological cancer $(n: 761)^{*}$} \\
\hline Yes & 30 & 3.9 \\
\hline No & 731 & 96.1 \\
\hline
\end{tabular}

*It is calculated from recordings.

Table 4: Pap smear outcomes of the women.

\begin{tabular}{|l|l|l|}
\hline $\begin{array}{l}\text { Pap-smear outcome ( } \\
\text { 1087) }\end{array}$ & $\mathbf{n}$ & $\mathbf{\%}$ \\
\hline Normal & 1071 & 98.5 \\
\hline ASCUS $^{*}$ & 3 & 0.3 \\
\hline HGSIL $^{* *}$ & 3 & 0.3 \\
\hline Not enough & 10 & 0.9 \\
\hline Total & 1087 & 100 \\
\hline
\end{tabular}

*ASCUS: Atypical Squamous Cells of Undetermined Significance

${ }^{* *}$ HGSIL : High-Grade Squamous Intraepithelial Lesion

Mean age for cervical cancer is 52 years and also it is highest between 35-39 and 60-64 years [21]. In our study 3 women with HGSIL were 60-64 aged and the ages of the women with ASCUS were 37, 53 and 59 years.

Among the risk factors for cervical cancer; low age for first intercourse $(<16$ years), number of sexual partner, high parity, race, low socioeconomic level and smoking take important place [22]. In our study, it is determined that 3 women with HGSIL lived at village but other information documents weren't recorded. So, effective risk factors couldn't evaluate. Two of women with ASCUS hadn't got any social guarantee, their first marriage and pregnancy age were 13-19 years, their number of pregnancy was 4 and more and they used intrauterine device as family planning method. Also it is determined that 3 women with ASCUS had got a family member with breast cancer. In our study, there was a meaningful difference between having social guarantee and number of birth with the women had ASCUS $(p<0.05)$. In the women who is polygamous and especially married before her 20, cervical cancer risk increase, distinctly [23]. We could state that our cases were in risk group especially because of their marriage and pregnancy ages and number of pregnancy. It is stated that early menarche age and short time between menarche age and first intercourse age are risk factors for cervical cancer [24]. In our study, menstrual age mean was almost 13 years and first marriage age of three in fourth of woman was 13-19 years (Table $1,2)$. This result shows that they started intercourse at an early age. However there wasn't any significant relationship between these parameters and the women had ASCUS or HGSIL $(p>0.05)$

Although pap-smear outcomes were normal in the most of the women in our study, it is thought that they should be done regular pap-smear tests because of their risk factors (Table 1,2).

In 2012, American Cancer Society and American College of Obstetricians and Gynecologists suggested that pap-smear screening ranges should be done between 21-29 ages in every 3 years and between 30-65 ages again in every 3 years, if only papsmear test is done. However, if this test is done with HPV test, it should be done in every 5 years for 30-65 aged women [25]. In a study of Ersöz, et al. 3000 women 24-64 aged were screened and $1.9 \%$ of them found with ASCUS [7]. In this study, this rate was $0.3 \%$. This high ASCUS diagnosis in other study could be because of the population which was taken from 24 years old. So, screening programs are suggested to start with 21 ages.

\section{Conclusion}

Nowadays, preventable methods for cancer and screening methods are in forefront mostly. Cervical cancer is a good sample that could be prevented by being protected. In our study, the woman with HGSIL was older than the others who had ASCUS. This result shows the importance of early diagnosis and screening. For being protected from cervical cancer, to know the factors that could be causes for this disease and importance of early diagnosis are important in terms of taking required measures. Giving educations about this subject to society, especially, groups that under risk, composing awareness related to increase to participation to the screening programs are important roles of nurses.

\section{Limitations of the Present Study}

The study is only limited records. It could not be generalized to the community.

\section{Acknowledgement}

The authors state that there are no financial or personal relationship conflicts of interests regarding this study.

${ }^{* *}$ The present study was presented as a oral presentations at I. National Women Health and Maternal and Child Health Congress on 18-19th of December, 2014 in İzmir, Turkey

\section{References}

1. Kurtoğlu E, Gürz AA. Cervix Cancer Epidemiology. Turkiye Clinics J Gynecol Obst-Special Topics. 2014;7(4):1-4. 
2. Globocan 2012:Estimated Cancer İncidence, Mortality and Prevalence Worldwide in 2002 -[cited 2015 January1 ]. Available from: http:// globocan.iarc.fr/Pages/fact_sheets_population.aspx

3. Preventing Cancer and Screening in Turkiye 2014 Brief report [cited 2015 January1]. Available from: http://kanser.gov.tr/kanser/ kanser-taramalari/1444-kanser-taramalar\%C4\%B1-k\%C4\%B1sarapor-2014.html

4. Bodur S, Eryılmaz MA, Civcik S, Durduran Y. The contribution of KETEM records to determination of cancers' distribution and incidence in population: the example of Konya. Journal of General Medicine. 2011;21(4):144-151.

5. Ayhan A, Dursun P, Kuşçu E, Mülayim B, Haberal N, Ozen O, et al. Prevalence of cervical cytological abnormalities in Turkey. Int J Gynaecol Obstet. 2009;106(3):206-9. doi: 10.1016/j.ijgo.2009.04.003.

6. Kurdoğlu Z, Kurdoğlu M, Kundakçı G, Keremoğlu Ö. Screening program outcomes for cervix and breast cancers belong to 'Van Cancer Early Diagnosis, Screening and Education Center. Van Medicine Journal. 2009;16(4):119-123.

7. Şafak Ersöz, Abdülkadir Reis, Nimet Baki. Cervical screening program in Trabzon county. J Turk Soc Obstet Gynecol. 2010;7(1):35-9.

8. Kög İ, Turan T, Karabük E, Karayünlü B, Özgü N, Demir ÖF, et al. Cervical and Breast Cancer Secreening Programme Results of Etlik KETEM Group. TAF Preventive Medicine Bulletin. 2012;11(2):145152.

9. Karabulut A, Alan T, Ali Ekiz M, Iritaș A, Kesen Z, Yahşi S. Evaluation of cervical screening results in a population at normal risk. Int J Gynaecol Obstet. 2010;110(1):40-2. doi: 10.1016/j.ijgo.2010.02.011.

10. Nazlıcan E, Akbaba M, Koyuncu H, Savaş N, Karaca B. Cervical Cancer Screening between 35-40 Aged Women at Kisecik Region of Hatay Provinence. TAF Prev Med Bull. 2010;9(5):471-474.

11. Kalyoncu C, Işıklı B, Özalp S, Küçük N. Knowledges, attitudes and behaviours of people who applied women disease and labour polyclinic of Osmangazi University. Health and Society. 2003;13:6068.

12. Gibbs RS, Karlan BY, Haney A.F, Naygard I. Danforth's Obstetrics and Gynecolocy. JB Lippincott Company. Philadelphia: 1997.
13. Turhal SN, Pekin T, Pekin S. Standard and Promising future screening attitutes related to cervix cancer etyology. T Clin Gynecol Obst. 1999;9:215-220.

14. Taşkın L. Birth and women's health nursing. 6th edition Ankara: Sistem ofset Matbaacllı. 2003:537-541.

15. Nygård JF, Skare GB, Thoresen SØ. The cervical cancer screening programme in Norway, 1992-2000: changes in pap smear coverage and incidence of cervical cancer. J Med Screen. 2002;9(2):86-91.

16. Parkin DM, Bray F, Ferlay J, Pisani P. Global cancer statistics 2002. CA A Cancer Journal for Clinicians. 2005; 55(2):74-108.

17. Van Leeuwen AW, NooijerP, Hop WC. Screening for cervical carcinoma. Cancer. 2005;105(5):270-276.

18. Chen YY, You SL, Chen CA, Shih LY, Koong SL, Chao KY, et al. Effectiveness of national cervical cancer screening programme in Taiwan: 12-year experiences. Br J Cancer. 2009;101(1):174-7. doi: 10.1038/sj.bjc.6605139.

19. Cancer screening statistics 2013 [cited 2015 January1]. Available from: http://kanser.gov.tr/Dosya/tarama/2013_tarama_istatistikleri.pdf

20. Nokiani FA, Akbari H, Rezaei M, Madani H, Ale Agha ME. Cost-effectiveness of pap smear in Kermanshah, Iran. Asian Pac J Cancer Prev. 2008;9(1):107-10.

21. Tuncer M, Özgül N, Olcayto E, Gültekin M. Cancer Control in Türkiye. Ankara; Koza Press. 2009.

22. Tuncer ZS. Serviks kanseri. In: Günalp S, Tuncer S, editors. Women diseases and labour diagnosis and treatment. Ankara: Pelikan Press. 2004:669-682.

23. Jemal A, Bray F, Center MM, Ferlay J, Ward E, Forman D. Global cancer statistics. CA Cancer J Clin. 2011;61(2):69-90. doi: 10.3322/ caac.20107.

24. Kanbur A, Çapık C. Cervical Cancer Prevention, Early DiagnosisScreening Methods and Midwives / Nurses Role. Hacettepe University Faculty of Health Sciences Nursing Journal. 2011;61-72.

25. Turkish Society of gynecologic onkology. Cervix cancer screening [cited 2016 March6]. Available from: http://www.trsgo.org/ menu/168/rahim-agzi-kanseri-taramasi 